\title{
Early Experiences with Stem Cells in treating Chronic Wounds
}

\section{Sadanori Akita $^{1 *}$, Hiroshi Yoshimoto ${ }^{1}$, Kozo Akino $^{1}$, Akira Ohtsuru ${ }^{2}$, Kenji Hayashida ${ }^{1}$, Akiyoshi Hirano', Keiji Suzuki ${ }^{3}$, Shunichi Yamashita ${ }^{2,3}$,}

${ }^{1}$ Department of Plastic and Reconstructive Surgery, ${ }^{2}$ Takashi Nagai Memorial International Hibakusha Medical Center, Nagasaki University Hospital, ${ }^{3}$ Atomic Bomb Disease Institute, Nagasaki University School of Medicine

Correspondence person: Sadanori Akita

1-7-1 Sakamoto, Nagasaki 852-8501, Japan.

e-mail: akitas@hf.rim.or.jp

Grant: Nagasaki University Global COE Program, "Global Strategic Center for Radiation Health Risk Control," by Japan Society for the Promotion of Science. 
KEYWORDS: Nagasaki , clinical study, adipose-derived stem cell therapy for local chronic radiation injury 


\section{Introduction: Wound healing process}

The wound healing process contains well-organized and integrated patterns of complex biological, molecular and gene-involvement events of:

- Cell proliferation

- Cell migration

- Differentiation capacity of cells

- Extracellular matrix (ECM) deposition and degradation

Within seconds, minutes, and hours after injury, both epidermal and dermal cell migration, proliferation, and differentiation initiate re-epithelialization (1). External injury may trigger tissue hypoxia, which leads to up-regulation of local growth factors (cytokines), degradation of ECM, and may ultimately lead to angiogenesis. Newly formed granulation tissue must be sustained in order to establish new blood vessel formation (2). Many diseases are related to keratinocyte or epidermal cell loss, angiogenesis dysfunction, and incomplete skin regeneration. These disorders including Beurger's disease, chronic radiation wounds, and other chronic wound healing problems are under clinical investigation for possible new therapeutic modalities. Autologous adipose-derived stem cells show great promise as an adjunct in facilitating the healing of these complex wounds.

\section{Pathogenesis of intractable or nonhealing wounds}

Skin wound healing comprises four major distinctive, but overlapping, phases:

1. Hemostasis

2. Inflammatory

3. Proliferation

4. Remodeling 
In a chronic wound, remarkable changes related to senescence, ischemia, matrix biology, and bacterial colonization transform the normal progression of wound healing into a self-continuing cycle of inflammation and injury (3). Injured tissue induces tissue hypoxia, which leads to upregulation of growth factors; degradation of ECM activates local angiogenesis. Stem cells have shown to promote angiogenic processes $(4,5,6)$. Stem cells also may be differentiated into various cells including fibroblasts, which are major component of dermis (7).

Chronic wounds include venous ulcers, pressure ulcers, and diabetic ulcers; these wounds may account for $90 \%$ of all nonhealing wounds (3). Venous ulcers are most frequently seen with high prevalence in woman (8) and are related to circulatory insufficiency and venous hypertension located in and around the malleolus. Pressure sores commonly occur in patients of impaired mobility, prolonged medical and surgical care such as extensive surgery, time spent in an intensive care unit (ICU), and poor systemic nutrition status. Pressure ulcers arise from external force, friction, and shear forcesthat affect segmental and perforator arteries leading to tissue necrosisparticularly over bony prominences (9). Diabetic ulcers result in long-term complications in diabetic patients. The majority of ulcers in diabetic patients are located in pressure points of the foot and can arise from peripheral neuropathy, foot deformity, and local minor trauma (10). In a diabetic wound, ischemia can result from macrovascular and microvascular disease, neuropathic disease, or all the aforementioned (11). Chronic wounds are complicated and etiologically multifactorial. Ischemia-reperfusion injury may play a major and important role in etiology (3). Ischemic stresses are altered in elderly people, partly due to combination of ischemia and oxidant stresses in the ischemia-reperfusion injury (12). Negative pressure wound therapy (NPWT) may prevent systemic damage caused by ischemic reperfusion, as demonstrated in a pig model (13). 
Wound healing contains multi-factorial local and systemic factors. Wound bed preparation involves management of the following parameters:

- tissue viability

- involvement of infection

- moisture balance

- wound edges

(14). In addition, local alteration of metalloproteinases, integrins, chemokines and growth factors on the wound surface must be controlled (15-17).

\section{Treatment of chronic wounds}

Treatment of chronic wounds is affected by optimal environmental conditions, the healing process, and subsequent scarring. Surgical or non-surgical debridement, reduction of edema, diminishing bacterial burdens, maintaining the favorable moisture balance, and removal of undermining tissues are included in standard wound care (18).

Wound characteristics can be modified with a variety of recently developed topical dressings such as impregnated gauze, film, hydrogel, hydrocolloid, and alginate. Advanced therapies include mechanical devices providing topical negative pressure and bioengineered tissues of various types(19-23). Even though vigorous development of such materials, devices, and products are underway, surgical debridement is still required to facilitate wound healing. Debridement can reduce bio-burden of a wound selectively and effectively. Necrotic tissue, which must be eliminated because it behaves as a substrate for proliferating bacteria that strives for the same nutrients and oxygen molecules essential for wound healing, is best removed with 
debridement.

\section{Stem cells in wound healing}

Stem cells are able to: (24).

- undergo self-renewal

- be cell proliferative

- differentiate into multiple lineages of cell and tissue phenotypes

Recent technological developments now allow isolation and culture of stem cells, which has enabled researchers to perform vigorous studies on somatic or adult stem cells.

Adult stem cells can differentiate into adipogenic, osteogenic, and neurogenic cell types (25). The autologous adult stem cells are readily available from the patient and not bothered by ethical and immunological barriers. Mesenchymal stem cells are first isolated from bone marrow and extend to almost all organs and tissues $(26,27)$. Bone marrow-derived stem cells from a single donor can differentiated into liver epithelium, lung, gastrointestinal tract, and skin $(28,29)$. Bone marrow-derived stem cells (BMMSC) are relatively easily obtained from bone marrow aspirates from donor patients. The BMMSC are isolated and expanded in vitro by sub-culturing (30). Human BMMSC are resistant to 20Gy radiation in vitro; immediately after 20 Gy radiations, reconstruction with hBMMSC and angiogenic growth factor (basic fibroblast growth factor, bFGF), artificial dermis demonstrated improved wound healing in 10 days (31).

A 58-year-old male patient had received 45 Gy of radiation and subsequently developed chest pain. He then underwent percutaneous transluminal coronary angioplasty (PTCA) 
under fluoroscopy, which was unexpectedly prolonged as a result of intra-operative complications. Immediately after the procedure, the patient noticed strong, deep, penetrating pain in his back. He subsequently developed a localized wound deep to the costal cartilage and a surrounding erythematic lesion which was apparent at first followup surgical visit. The wound was widely excised, including the necrotic cartilage. It was reconstructed with a bilobed latissimus dorsi musculo-cutaneous flap. The scar tissue resulting from original radiation was further analyzed histologically for cellular analysis. [Joanne - not sure how to express "detection of cells property" Were they looking for growth factors? Collagen?] Small spindle-shaped cells were concentrated within the fibrotic tissue and Stro-1, which is one of immuno-reactive markers of mesenchymal stem cells (32). This finding suggested that stem cells may mediate a radiation injury (Figure 1).

BMMSC can synthesize higher amount of collagen, FGF, and vascular endothelial growth factor (VEGF), suggesting a potential benefit in accelerating wound healing (33). Human BMMSC are able to accelerate wound healing with a collagen sponge with bFGF (34). Over a 1-year period of observation of autologous bone marrow cell treatment for three nonhealing wounds, which previously failed to heal with the use of bioengineered skin or skin grafting, complete closure and dermal rebuilding in all cases was demonstrated with autologous bone marrow cell. Reduced scarring and engraftment of grafted cells was observed (35). Fibrin polymer spray, in which fibrinogen contains cultured autologous BMMSC, can adhere to the wound bed and retain the cell viability and migration (36). Cultured BMMSC are used for severe radiation associated wounds with numerical dosimetry-guided surgery followed up to 11 months (37). Also, cultured BMMSC are effective for intractable wounds when soaked in an artificial dermis (38). In addition, direct injection of cultured BMMSC into the wound area in normal diabetic mice 
promoted wound healing through release of proangiogenic factors upon differentiation (39). ; In streptozocin (STX)-induced diabetic rats, BMMSC double-system injections through the tail vein and local injection at the wound site augmented growth factors such as EGF, VEGF, PDGFBB markedly and TGF- $\beta$ and KGF moderately (40). BMMSC induce potent differentiation and proliferation under low oxygen tension with cell morphological and cell cycle changes and differentiation capacity towards bone and fat (42).

Furthermore, Human BMMSC transplantation to an adult rabbit incisional wound demonstrated tensile strength 80 days post-surgery (48). Systemic administration of rat BMMSC for 4 days promotes wound healing, increases production of collagen, rapid maturation of wound, and increases the tensile strength (49).

Stem cells are found in very low amounts among the nucleated cells from the bone marrow and even lesser amounts in peripheral blood. Fibroytes originate in bone marrow (50) and are found in peripheral blood, wounds, and tissue remodeling (51). A recent study of peripheral blood demonstrated fibrocytes are able to proliferate cells, and induce re-epithelialization and angiogenesis in a diabetic mouse (17).

\section{Adipose-derived stem cells}

Fat tissues contain multipotent cells, with similar wound healing effects of BMMSC, stimulating human dermal fibroblasts (52). They have the capacity to differentiate into adipogenic, chondrogenic, myogenic, and osteogenic cell lineage when cultured in vitro with similar cell surface CD antigens $(53,54)$. Adipose-derived stem cells (ADSC) are obtained either from liposuction procedure or solid fat tissue. ADSC are called adipose-derived regenerative cells, because it contains heterogeneous inducible "regenerative" cells (55). ADSC are more easily 
obtained from the donor sites than BMMC and extensively proliferative ex vivo in vitro. Fat tissue plays an important role in regulating energy balance and substance metabolism and its biological function in terms of metabolism, hormone and signaling are varying (56). In vitro, assay, depending on the anatomical location of the donor sites, age and gender may be different in yielding and differentiation capacity (57). ADSC are approximately 5,000 CFU-F per gram of adipose tissue while the estimate CFU-F per Milliliter of bone marrow is 100 to 1,000 (58). Comparing lipoaspirate and excised adipose tissues, aspirated adipose tissue yields more preadipocytes within 60 minutes after extraction and at 24 hours storage at 4 degrees than extracted tissue (59). Though distinction of preadipocytes from ADSC via lipoaspiration is still unknown, it is acknowledged that preadipocytes can be used for fat-based regeneration (60). There are several reasons that ADSC are most favorable cell sources for regeneration:

- The lipoaspiration procedure is relatively common for surgeons.

- ADSCs contain superior potentials to induce both angiogenesis and vasculogenesis (61).

- In vivo studies prove the efficacy and effectiveness using ADSCs (62).

- ADSCs are easily cultured and have high-affinity with three dimensional scaffolds and other cells (63).

\section{Adipose-derived stem cells in wound healing}

ADSCs are available for promoting angiogenesis, secreting growth factors and cytokines and differentiating into multiple cell types upon stimuli. ADSCs can promote human dermal fibroblast proliferation by directly contacting cells and paracrine activation in re-epithelialization phase of wound healing (52). Two-dimensional gel electrophoretic gel proteomic analysis of intracellular protein of BMMSC and ADSC resulted in the similar protein. This suggests that 
ADSC can replace BMMSC in cell therapy (64). ADSC-treated mouse wounds healed faster than with normal process. In nonirradiated and locally-irradiated mouse wounds, ADSC can be differentiated to keratinocytes and produce keratinocyte growth factor (KGF) as well as vascular endothelial growth factor (VEGF) (65). ADSC can release angiogenic factors in ischemic injury. ADSCs in acellular dermal matrix provide a framework for support of the regenerative capacity in wound healing (66).With appropriate scaffolds, ADSC can cause regeneration and induce wound healing. ADSCs with skin substitute containing human extracellular matrix can produce subcutaneous, dermal, and epidermal regenerated tissues (67). Using clinically available human acellular dermal matrix of cadaveric donors, ADSCs demonstrated accelerated wound healing by 7 days post-operatively and microvascular endothelial phenotype for 2 weeks, indicating the direct vascular networking in tissue regeneration with no systemic distribution other than surgical engrafted sites (68).

In a diabetic mouse model, noncultured-excised ADSC with commercially available bilayer artificial dermis can secrete a great number of growth factors and cytokines at 4 days in cell culture supernatants, histological advanced granulation tissue formation, capillary formation, and epihelialization for 2 weeks post-operatively (69).

In a pig multiple full-thickness wound model, cultured ADSC with presence of platelet-rich plasma can enhance the wound healing process in terms of VEGF concentration in the fluid and cosmetic appearance (70). ADSC are able to demonstrate anti-oxidant effect via dermal fibroblasts and keratinocytes in a paracrine manner (71) and hypoxia increases VEGF and bFGF as well as induces cell proliferation (72). 


\section{Adipose-derived regenerative cell therapy for chronic radiation injury}

\section{Background of adipose-derived regenerative cell therapy}

Although the literatures emphasizes the merit and advantage of ADSC or adipose-derived regenerative cell (ADRC) use in wound healing, there are currently few clinical applications. Autologous cultured BMMSCs are now being used to treat severe radiation injury (73). The purified autologous lipoaspirates are injected to improve radiation ulcers (74).

\section{Nagasaki University Global Strategic Center for Radiation Health Risk Control}

This clinical study project is designed under "Nagasaki University Global Strategic Center for Radiation Health Risk Control", which is one of the global center-of-excellence (GCOE) programs funded by the Ministry of Education, Culture, Sports and Technology from 2007 to 2011. The aim of this program is to focus on global assessment of radiation and effect to health risk, to overcome the legacy of atomic-bombing, to establish the scientific basis of human safety to radiation, and to promote international collaboration that will nurture the experts in this field. In order to accomplish these aims three research projects are set:

1. radiation and nuclear basic life science research

2. atomic-bomb disease medical research

3. international radiation health science research

The goal of this project is to establish the scientific basis of radiation health risk control to contribute to society through Hibaku/Hibakusha (radiation-exposed) medicine. Radiation basic life science research investigates external and internal irradiation, mechanisms of chronic low- 
dose radiation, and risk assessment and management, susceptibility, and racial difference in individual risk assessment. Atomic-bomb disease medial research deals with aging of the atomicbomb survivors who have progressive cancer, multiple cancer, and psycho-somatic effects, and also treating foreign Hibakusha-atomic-bomb survivors. Lastly, international radiation health science research handles broad aspects of threat of nuclear events, global nuclear power plant (NPP) accidents and disasters and world health organization-radiation emergency medical assistance and networking (WHO-REMPAN) collaboration center activity. Through WHOREMPAN collaboration center, development and clinical application of regenerative medicine is further promoted (Figure 2). As acute systemic radiation injuries are rare and unpredictable, the possibility of applying patients' own fat tissue-derived stem cell therapy of their subcutaneous tissues not exposed to radiation for chronic local radiation injury is attempted.

\section{Patient enrollment}

Five clinical treatment experiences with autologous noncultured ADSC for more than 18 months, which is considered the final phase of wound healing remodeling process (1), mean patients' follow-up period was 2 years \pm 6 months ( 2 years 10 months to 1 year 9 months) postoperatively. All five cases uneventfully healed, average healing $8 \pm 2.2$ weeks, among which one patient was treated for her consistent pain in her left toes as a result of thromboangitis due to Beurger's disease. Mean age of the patient was $64.4 \pm 22.0$ and all are female. There is no recurrence or abnormal wound healing during follow-up periods in any of the cases.

\section{Surgical procedure, scaffold (artificial dermis) and growth factor}

In adipose-derived stem cell transplantation and post-operative management, an artificial dermis 
(Terudermis ${ }^{\circledR}$, Olympus-Terumo Biomaterials Co.,Ltd., Japan) was used as a scaffold.

Terudermis ${ }^{\circledR}$ is composed of two layers: a lower layer of bovine atelocollagen and an upper layer comprising a silicone sheet which protects against infection and dryness from the outside.

- After minimum debridement, Terudermis ${ }^{\circledR}$ was multilayered and stacked over freshly debrided wounds.

- The silicone sheets were removed except top Terudermis ${ }^{\circledR}$.

- Two-thirds of isolated ADSCs were injected around the debrided wound at the base of the wounds, and into Terudermis®.

- Another one-third of ADSCs was mixed with the autologous adipose which was rinsed with a lactated Ringer's solution.

- In the Celution system, after isolating ADSCs, the disposable cell collection plastic case was again used to mix the suctioned fat, which is rinsed separately in the 50-cc syringe and repeated until the oil droplets are removed.

- After being mixed, it was injected into a zone of hard fibrotic tissue around the debrided wounds in 2-cm width in all directions.

Detailed surgical procedure is described in the literature (75). Briefly, surgical debridement is limited to the most severely affected area in depth and in width. The cells are injected at the edges and the base evenly washed fat tissue mixed with cells are injected to bridge between the wound and intact tissue (Figure 3).

Angiogenic growth factor, basic fibroblast growth factor (bFGF), genetically recombinant human bFGF (Fiblast, Trafermin) was purchased from Kaken Pharmaceutical Co., Inc (Tokyo, Japan). The Freeze-dried bFGF was dissolved in $5 \mathrm{~mL}$ of benzalkonium chloride containing solution 
right before the first use and stored at $4{ }^{\circ} \mathrm{C}$ for one day, with $300 \mu \mathrm{L}$ sprayed over $30 \mathrm{~cm}^{2}$ area from $5 \mathrm{~cm}$ distance and $0.3 \mathrm{~mL}$ per day of this solution was applied over the wound when the outer layer of the artificial dermis is naturally peeled off and administration of bFGF starts 3 to 7 days post-operatively. The wound was covered with non-adherent occlusive foam dressing. All cases demonstrated complete wound healing by 10 weeks post-operatively.

Case: An 87-year-old female was treated for uterine cervical cancer. 50 Gy of two-gate radiation was performed 40 years previously. The wound reached to the sacral bone, para-vertebral muscles and ligaments. The radiation injury caused central wounding and massive exudate. Several surgical treatments were carried out with artificial dermis alone, artificial dermis with bFGF or split-thickness skin grafting. None was successful and wounding recurred within several weeks. The most severe part of wound was surgically debrided and $3.7 \times 10^{7}$ cells were injected at the edges and the base. The fat tissue mixed cells bridged between the wound margin and intact tissue. The wound was covered with Terudermis ${ }^{\circledR}$ and the outer membrane remained in place for one week, then bFGF was sprayed. The wound healed 72 days post-operatively. Hypertrophic scar developed at 180 days but there is no hypertrophic scar or recurrence of wound at 970 days post-operatively. A small portion of the processed cells are cultured in vitro for confirmation of cell proliferation and capacity of differentiation. The cultured cells demonstrated stem cell properties (Figure 4) (Figure 5).

\section{Key Points: "take home" points of the discussion}


Stem cell biology and application in wound healing is widely studied for bone marrow-derived stem cells (BMMSC).

Adipose-derived stem cells (ADSC) are more easily obtained from the donor sites..

In chronic radiation injury a mixture of ADSC and aspirated adipose tissue may play a pivotal role in wound healing.

\section{Summary box of Pearls \& Pitfalls regarding the treatment}

ADSC are relatively easy to harvest and process.

In very lean patients, ADSC may need to be cultured.

\section{Summary box of "first-person experience" by author}

- Active ADSC can be harvested in elderly patients

- In cell culture, these cells are able to proliferate and differentiate into adipose tissue.

- Even an 87 year old patient was able to heal a radiation related ulcer of the sacrum with the assistance of ADSC.

\section{Techniques summary}

The harvesting equipment is configured in a closed circuit in order to minimize the risk of contamination. When harvesting subcutaneous adipose tissue, one should be cautious to not penetrate into deeper structures such as visceral cavity in abdomen or major muscles, vessels and nerves. 
In injecting ADSC/ADRC in chronic radiation injury sites, care should be taken to avoid surface rupture or laceration.

\section{References}

1. Martin P. Wound healing-aiming for perfect skin regeneration. Science. 1997; 276:75-81.

2. Brem H, Tomic-Canic M. Cellular and molecular basis of wound healing in diabetes, J Clin Invest. 2007;117:1219-1222.

3. Mustoe T, O'Shaughnessy K, Kloeters O. Chronic wound pathogenesis and current treatment strategies: a unifying hypothesis. Plast Reconstr Surg. 2006;1117(Suppl 7):S35-41.

4. Hanjaya-Putra D, Gerecht S. Vascular engineering using human embryonic stem cells. Biotechnol Prog. 2009;25:2-9.

5. Sorrell J, Baber M, Caplan A. Influence of adult mesenchymal stem cells on in vitro vascular formation. Tissue Eng Part A. 2009;15:1751-1761.

6. Wu Q, Shao H, Darwin ED, et al. Extracellular calcium increases CXCR4 expression on bone marrow-derived cells and enhances pro-angiogenesis therapy. J Cell Mol Med. 2009;13:37643773.

7. Watkins S, Zippin J. When wound healing goes awry. A review of normal and abnormal wound healing, scar pathophysiology and therapeutics. J Drugs Dermatol. 2008;7:997-1005.

8. Heit J, Rooke T, Silverstein M, et al. Trends in the incidence of venous statis syndrome and venous ulcer: a 25-year population-based study. J Vasc Surg. 2001;33:1022-7.

9. Rogers A, Burnett S, Moore $\mathrm{J}$, et al. Involvement of proteolytic enxymes-plasminogen activators and matrix metalloproteinases-in the pathophysiology of pressure ulcers. Wound Repair Regen. 1995;3:273-283. 
10. Boulton AJ. The diabetic foot: a global view. Diabetes Metab Res Rev. 2000;16(Suppl 1):S2S5.

11. Gershater MA, Londahl M, Nyberg P, et al. Complexity of factors related to outcome of neuropathic and neuroischaemic/ischaemic diabetic foot ulcers: a cohort study. Diabetologia. 2009; 52:398-407.

12. Mogford JE, Liu WR, Reid R, et al. Adenoviral human telomerase reverse transcriptase dramatically improves ischemic wound healing without detrimental immune response in an aged rabbit model. Hum Gene Ther. 2006;17:651-60.

13. Kubiak BD, Albert SP, Gatto AL, et al. Peritoneal negative pressure therapy prevents multiple organ injury in a chronic porcine sepsis and ischemia/reperfusion model. Shock. 2010;34:52534.

14. Schultz GS, Sibbald RG, Falanga V, et al. Wound bed preparation: a systemic approach to wound management. Wound Repair Regen. 2003;11:S1-28.

15. Nedeau AE, Gallagher KA, Liu ZJ, et al. Elevation of hemopexin-like fragment of matrix metalloproteinase-2 tissue levels inhibits ischemic wound healing and angiogenesis. J Vasc Surg. 2011; Epub ahead of print.

16. Hamed S, Ulmann Y, Egozi D, et al. Fibronectin potentiates topical erythropoietin-induced wound repair in diabetic mice. J Invest Dermatol. 2011;131:1365-74.

17. Kao HK, Chen B, Murphy GF, et al. Peripheral blood fibrocytes: enhancement of wound healing by cell proliferation, re-epithelialization, contraction, and angiogenesis. Ann Surg. 2011; Epub ahead of print.

18. Ligresiti C, Bo F. Wound bed preparation of difficult wounds: an evolution of the principles of TIME. Int Wound J. 2007;4:21-9. 
19. Macri L, Clark RA. Tissue engineering for cutaneous wounds: selecting the proper time and space for growth factors, cells and the extracellular matrix. Skin Pharmacol Physiol. 2009;22:83-93.

20. Smiell JM, Wieman TJ, Steed DL, et al. Efficacy and safety of becaplemin (recombinant human platelet-derived growth factor-BB) in patients with nonhealing, lower extremity diabetic ulcers: a combined analysis of four randomized studies. Wound Repair Regen. 1998;7:335-46.

21. Robson MC, Phillips LG, Lawrence WT, et al. The safety and effect of topically applied recombinant basic fibroblast growth factor on healing of chronic pressure sores. Ann Surg. 1992;216:401-16.

22. Marston WA, Hanft J, Norwood P, et al. The efficacy and safety of Dermagraft in improving the healing of chronic diabetic foot ulcers: results of a prospective randomized trial. Diabetes Care. 2003;26:1701-5.

23. Falanga V, Sabolinksi M. A bilayered living skin construct (APLIGRAF) accelerates complete closure of hard-to-heal venous ulcers. Wound Repair Regen. 1999;7:201-7.

24. Anderson DJ, Gage FH, Weissman IL. Can stem cells cross lineage boundaries? Nat Med. 2001;7:393-5.

25. Montanucci P, Basta G, Pescara T, et al. New simple and rapid method for purification of mesenchymal stem cells from the human umbilical cord Wharton jelly. Tissue Eng Part A. 2011, epub ahead of print.

26. Pittenger MF, McKay SC, Beck RK, et al. Multi-lineage potential of adult human mesenchymal stem cells. Science. 1999;284:143-47.

27. da Silva Meirelles L, Chagastelles PC, Nardi NB. Mesenchymal stem cells reside in virtually 
all post-natal organs and tissues. J Cell Sci. 2006;119(Pt 11):2204-13.

28. Krause DS, Theise ND, Collector MI, et al. Multi-organ, multilineage engraftment by a single bone marrow-derived stem cell. Cell. 2001;105:369-77.

29. Badiavas EV, Abedi M, Butmarc J, et al. Participation of bone marrow derived cells in cutaneous wound healing. J Cell. Physiol. 2003;196:245-50.

30. Barry FP, Murphy JM. Mesenchymal stem cells: clinical applications and biological characterization. Int J Cell Biol. 2004;36:568-84.

31. Akita S, Akino K, Hirano A, et al. Mesenchymal stem cell therapy for cutaneous radiation syndrome. Health Phys. 2010;98:858-62.

32. Ning H, Lin G, Lue TF, et al. Mesenchymal stem cell marker stro- is a 75kd endothelial antigen. Biochem Biophys Res Commun. 2011;413:353-7.

33. Han SK, Yoon TH, Lee DG, et al. Potential of human bone marrow stromal cells to accelerate wound healing in vitro. Ann Plast Surg. 2005;55:414-9.

34. Nakagawa H, Akita S, Fukui M, et al. Human mesenchymal stem cells successfully improve skin-substitute wound healing. Br J Dermatol. 2005;153:29-36.

35. Badiavas EV, Falanga V. Treatment of chronic wounds with bone marrow-derived cells. Arch Dermatol. 2003;139:510-6.

36. Falanga V, Iwamoto S, Chartier M, et al. Autologous bone marrow-derived cultured mesenchymal stem cells delivered in a fibrin spray accelerates healing in murine and human cutaneous wounds. Tissue Eng. 2007;13:1299-312.

37. Lataillade JJ, Doucet C, Bey E, et al. New approach to radiation burn treatment by dosimetryguided surgery combined with autologous mesenchymal stem cell therapy. Regen Med. 2007;2:785-94. 
38. Yoshikawa T, Mitsuno H, Nonaka I, et al. Wound therapy by marrow mesenchymal cell transplantation. Plast Reconstr Surg. 2008;121:860-77.

39. Wu Y, Chen L, Scott PG, et al. Mesenchymal stem cells enhance wound healing through differentiation and angiogenesis. Stem Cells. 2007;25:2648-59.

40. Kwon DS, Gao X, Liu YB, et al. Treatment with bone marrow-derived stromal cells accelerates wound healing in diabetic rats. Int Wound J. 2008;5:453-63.

41. Sasaki M, Abe R, Fujita Y, et al. Mesenchymal stem cells are recruited into wounded skin and contribute to wound repair by trasdifferentiation into multiple skin cell type. J Immunol. 2008;180:2581-7.

42. Ren H, Cao Y, Zhao Q, et al. Proliferation and differentiation of bone marrow stromal cells under hypoxic conditions. Biochem Biophys Res Commun. 2006;347:12-21.

43. Nedeau AE, Bauer RJ, Gallagher K, et al. A CXCL5- and bFGF-dependent effect of PDGFB-activated fibroblasts in promoting trafficking and differentiation of bone marrow-derived mesenchymal stem cells. Exp Cell Res. 2008;314:2176-86.

44. Grayson WL, Zhao F, Bunnell B, et al. Hypoxia enhances proliferation tissue formation of human mesenchymal stem cells. Biochem Biophys Res Commun. 2007;358:948-53.

45. Chen L, Tredget EE, Wu PY, et al. Paracrine factors of mesenchymal stem cells recruit macrophages and endothelial lineage cells and enhance wound healing. PLoS One. 2008;3:e1886.

46. Smith AN, Willis E, Chan VT, et al. Mesenchymal stem cells induce dermla fibroblast responses to injury. Exp Cell Res. 2010;316:48-54.

47. Alfaro MP, Pagni M, Vincent A, et al. The Wnt modulator sERP2 enhances mesenchymal stem cell engraftment, granulation tissue formation and myocardial repair. Proc Natl Acad Sci USA. 
2008;105:18366-71.

48. Stoff A, Rivera AA, Sanjib Banerjee N, et al. Promotion of incisional wound repair by human mesenchymal stem cell transplantation. Exp Dermatol. 2009;18:362-9.

49. McFarlin K, Gao X, Liu YB, et al. Bone marrow-derived mesenchymal stromal cells accelerates wound healing in the rat. Wound Repair Regen. 2006;14:471-8.

50. Mori L, Bellini A, Stacey MA, et al. Fibrocytes contribute to the myofibroblast population in wounded skin ad originate from the bone marrow. Exp Cell Res. 2005;304:81-90.

51. Bucala R, Spiegel LA, Chesney J, et al. Circulating fibrocytes define a new leukocyte subpopulation that mediates tissue repair. Mol Med. 1994;1:71-81.

52. Kim WS, Park BS, Sung JH, et al. Wound healing effect of adipose-derived stem cells: a critical role of secretory factors on human dermal fibroblasts. J Dermatol Sci. 2007;48:15-24.

53. Zuk PA, Zhu M, Mizuno H, et al. Multilineage cells from human adipose tissue: implications for cell-based therapies. Tissue Eng. 2001;7:21-28.

54. Zuk PA, Zhu M, Ashjian P, et al. Human adipose tissue is a source of multipotent stem cells. Mol Biol Cell. 2002;13:4279-95.

55. Kondo K, Shintani S, Shibata R, et al. Implantation of adipose-derived regenerative cells enhances ischemia-induced angiogenesis. Arterioscler Thromb Vasc Biol. 2009;29:61-6.

56. Giorgino F, Laviola L, Eriksson JW. Regional differences of insulin action in adipose tissue: insights form in vivo and in vitro studies. Acta Physiol Scand. 2005;183:13-30.

57. Schipper BM, Marra KG, Zhang W, et al. Regional anatomic and age effects on cell function of human adipose-derived stem cells. Ann Plast Surg. 2008;60:538-44. 
58. Strem BM, Hicok KC, Zhu M, et al. Multipotential differentiation of adipose tissue-derived stem cells. Keio J Med. 2005;54:132-41.

59. von Heimburgh D, Hemmrich K, Haydarlioglu S, et al. Comparison of viable cell yield form excised versus aspirated adipose tissue. Cells Tissues Organs. 2004;178:87-92.

60. Tholpady SS, Aojanepong C, Llull R, et al. The cellular plasticity of human adipocytes. Ann Plast Surg. 2005;54:651-6.

61. Nie C, Yang D, Xu J, et al. Locally administered adipose-derived stem cells accelerate wound healing through differentiation and vasculogenesis. Cell Transplant. 2011;20:205-16.

62. Strem BM, Hedrick MH. The growing importance of fat in regenerative medicine. Trends Biotechnol. 2005;23:64-6.

63. Neofytou EA, Chang E, Patlola B, et al. Adipose tissue-derived stem cells display a proangiogenic phenotype on 3D scaffolds. J Biomed Mater Res A. 2011;98:383-93.

64. Roche S, Delorme B, Oostendorp RA, et al. Comparative proteomic analysis of human mesenchymal and embryonic stem cells: towards the definition of a mesenchymal stem cell proteomic structure. Proteomics. 2009;9:232-33.

65. Ebrahimian TG, Pouzoulet F, Squiban C, et al. Cell theraoy baed on adipose tissue-derived stromal cells promotes physiological and pathological wound healing. Arterioscler Thromb Vasc Biol. 2009;29:503-10.

66. Nie C, Yang D, Morris SF. Local delivery of adipose-derived stem cells via acellular dermal 
matrix as a scaffold: a new promising stragtegy to accelerate wound healing. Med Hypotheses. 2009;72:679-82.

67. Trottier V, Marceau-Fortier G, Germain L, et al. IFATS collection: Using human adiposederived stem/stromal cells for the production of new skin substitutes. Stem Cells. 2008;26:2713-23.

68. Altman AM, Matthias N, Yan Y, et al. Dermal matrix as a carrier for in vivo delivery of human adipose-derived stem cells. Biomaterials. 2008;29:1431-42.

69. Nambu M, Kishimoto S, Muzuno H, et al. Accelerated wound healing in healing-impaired $\mathrm{db} / \mathrm{db}$ mice by autologous adipose tissue-derived stromal cells combined with atelocollagen matrix. Ann Plast Surg. 2009;62:317-21.

70. Blanton M, Hadad I, Johnstone B, et al. Addipose stromal cells and platelet-rich plasma therapies synergistically increase revascularization during wound healing. Plast Reconsr Surg. 2009;123(2 suppl):56S-64S.

71. Kim WS, Park BS, Sung JH. The wound-healing and antioxidant effects of adipose-derived stem cells. Expert Opin Biol Tjer. 2009;9:879-87.

72. Lee EY, Xia Y, Kim WS, et al. Hypoxia-enhanced wound-healing function of adipose-derived stem cells: increase in stem cell proliferation and upregulation of VEGF and bFGF. Wound Repair Regen. 2009; 17:540-7.

73. Bey E, Prat M, Duhamel P, et al. Emerging therapy for improving wound repair of severe radiation burns using local bone marrow-derived stem cell administrations. Wound Repair 
Regen. 2010;18:50-8.

74. Rigotti G, Marchi A, Galie M, et al. Clinical treatment of radiotherapy tissue damage by lipoaspirate transplant: a healing process mediated by adipose-derived adult stem cells. Plast Reconostr Surg. 2007;119:1409-22.

75. Akita S, Akino K, Hirano A, et al. Noncultured autologous adipose-derived stem cells therapy for chronic radiation injury. Stem Cells Int. 2010;2010:52704. 


\section{Figure legends}

Figure 1: STRO-1 immuno-reactivity in the radiation induced wound and subsequent scarring from a 58-year-old male patient's back

A:

1: Radiation injury with exposed costal rib and central tissue necrosis at first visit, 2 years after fluoroscopic procedure

2: In the reverse side of injury, scarring was observed at periphery of the base was very hard.

3: 2 years after reconstruction by latissimus dorsi musculo-cutaneous flap (bilobed flap)

4: small fusiform cells were abundant in the scar tissue.

B: Scarred tissue was immunohistological analysis of STRO-1

In the right, scarred tissue explanting cell culture demonstrated Steo-1 immuno-reacivity in cell cytoplasm in the right.

Figure 2: Scheme of Nagasaki University Global Strategic Center for Radiation Health Risk Control

A: Global focal points of collaboration with Nagasaki University

B: Strategy applying to promoting innovative therapy such as ADSC for radiation injury is a part of this project

Figure 3: Schematic principles of progression of chronic radiation injury 
A: Once external radiation is administered.

B: For therapeutic radiation, dose is usually greater in deeper in the tissue as the target organ is often located deep

$\mathrm{C}$ : Radiated tissue is getting sclerotic in process of chronic radiation injury

D: Surgical debridement is aimed at the wounded and most severe areas

E: ADSC are injected or soaked around wound margins and wound bed

F: Stacked artificial dermis (Terudermis $\left.{ }^{\circledR}\right)$ and liposuctioned adipose tissue mixed wit

ADSC

are bridged with the adjacent intact tissue

Figure 4: An 87-year-old female was treated for uterine cervical cancer. A 50 Gy of two gate

radiation was performed 40 years previously and wound was reached to the sacral

bone, muscle and ligament

1: pre-op

2: intra-op

3: intra-op with artificial dermis

4: 36 days 
5: 72 days, linear hypertrophic scar formation

6: 970 days, wound healed and pliable

Figure 5: In vitro cell proliferation and differentiation

1: adipose-derived stem cells in regular cell culture medium at day 2

2: adipose-derived stem cells in ES cell culture medium at day 9

3: adipose-derived stem cells in ES cell culture medium at day 16 at confluent

4: adipose-derived stem cells in ES cell culture medium at day 16 by differentiation induction

5: adipose-derived stem cells in ES cell culture medium at day 16, lipid is marled in red by OilRed O staining 
Figure 1A

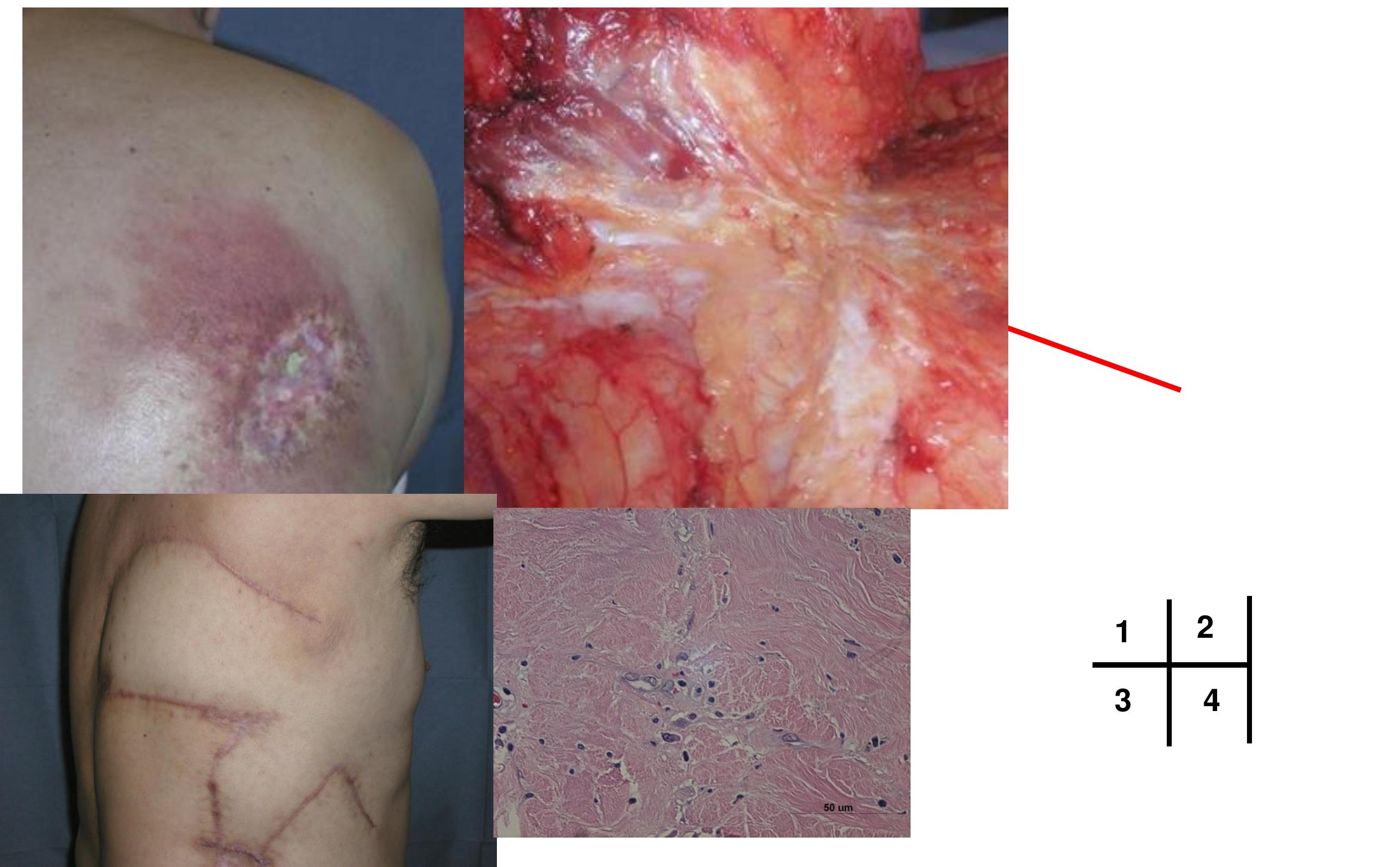


Human mesenchymal stem cells in vitro

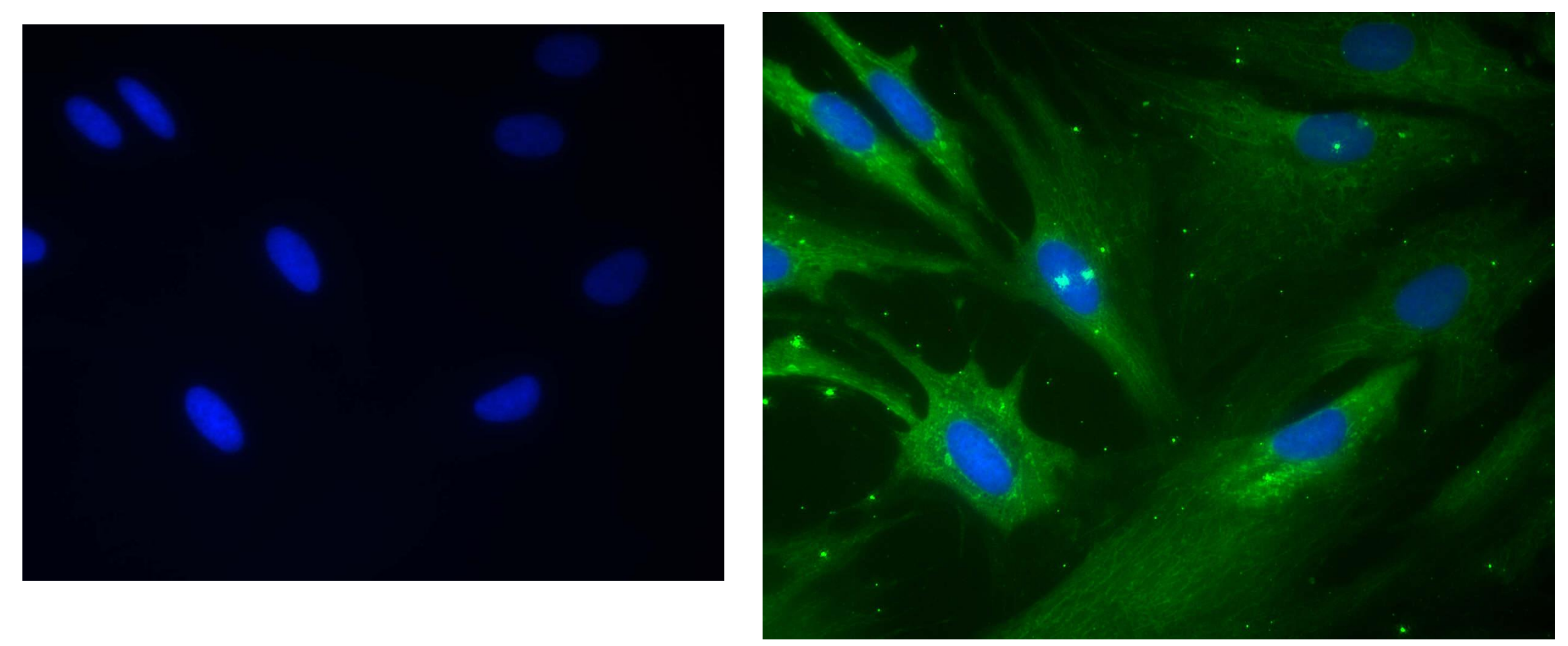


Figure 2A

Nagasaki University Global Strategic Center for Radiation Health Risk Control

\section{Combine international educational institutes}

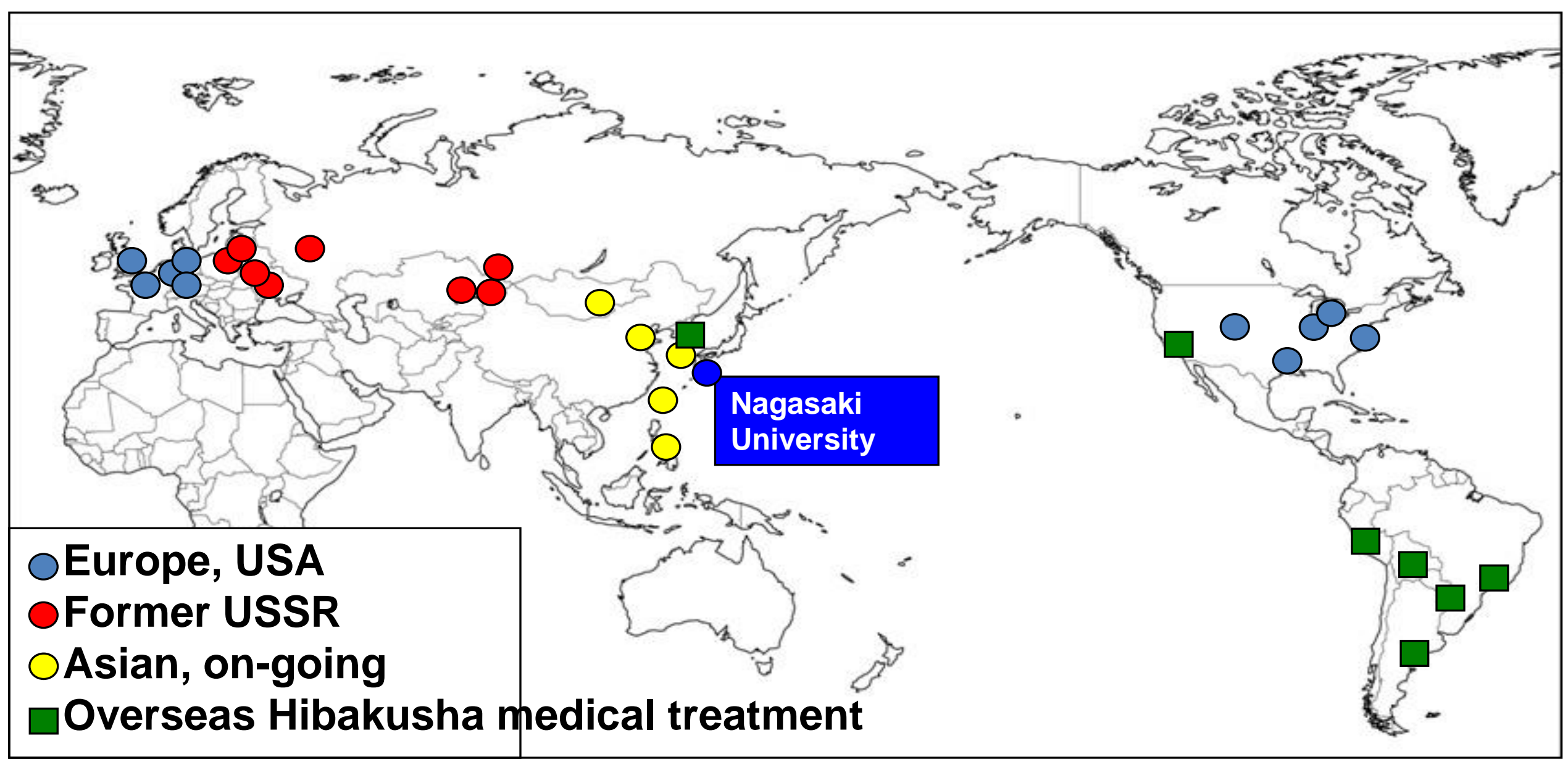


From genomic research to radiation health risk management and application of innovation

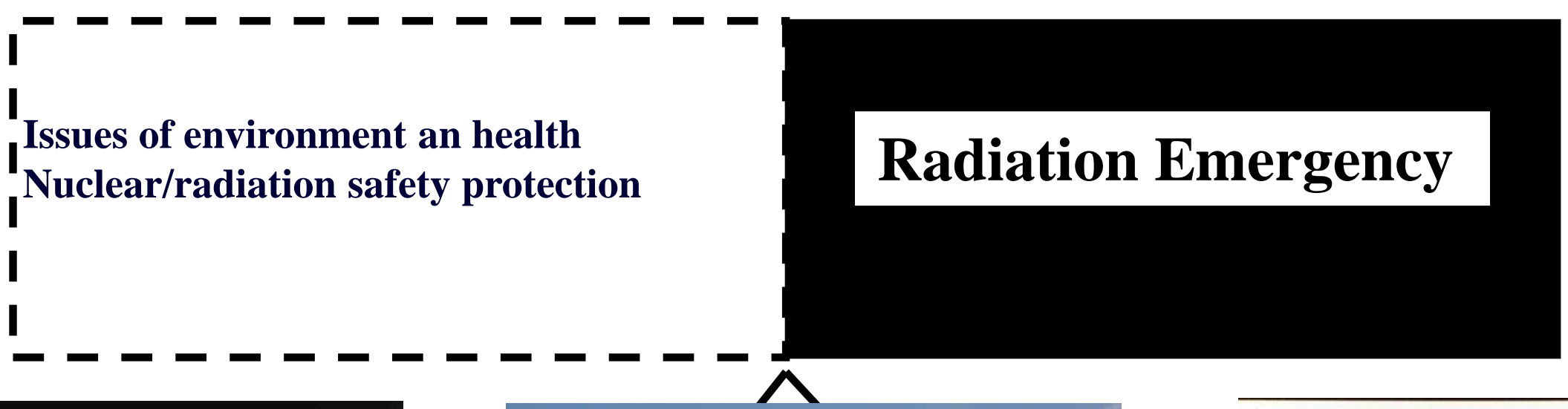

\section{Medical Irradiation}
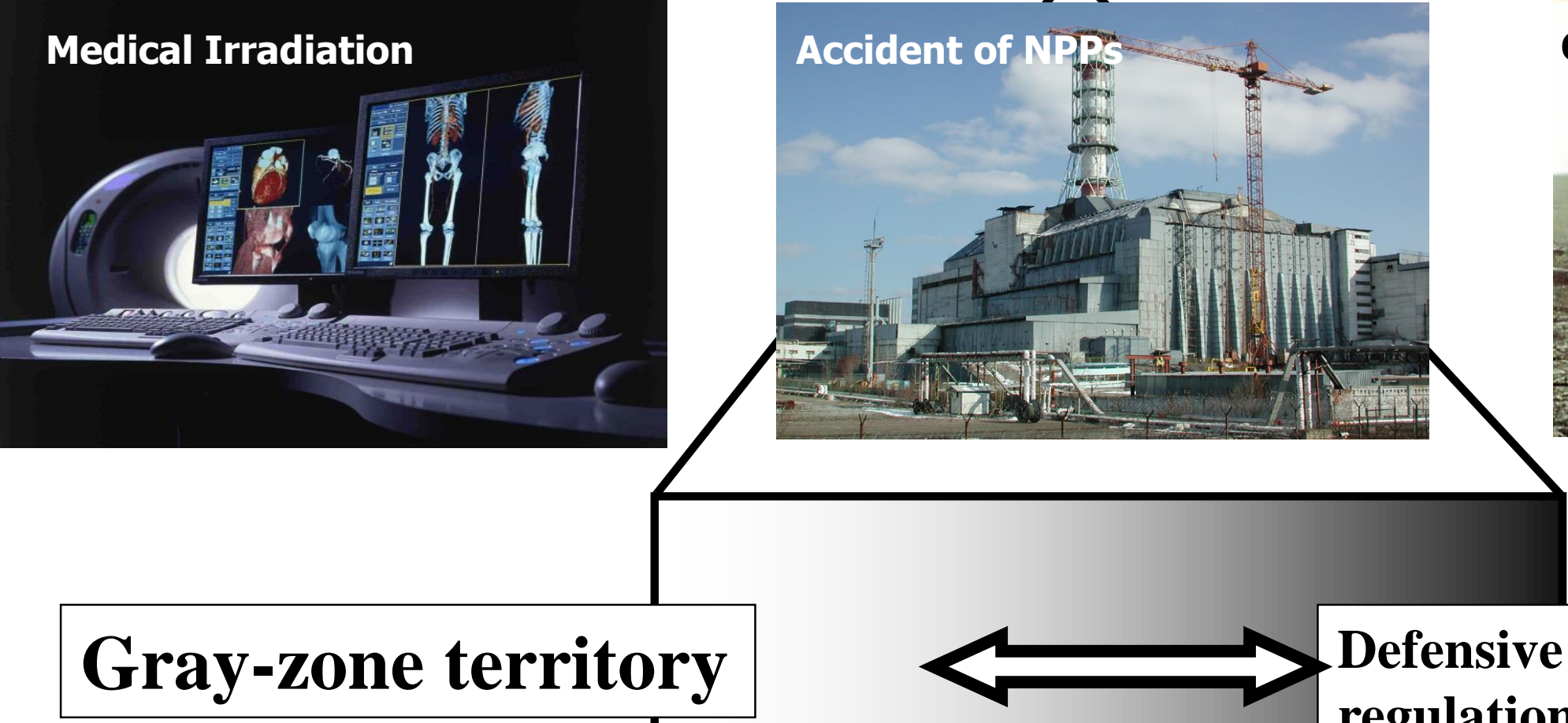

Conflict/war, nuclear terrorism

Defensive science regulation science

Promoting innovative therapy

Radiation genomic research, health risk management, innovative therapy 
Figure $3 \mathrm{~A}$
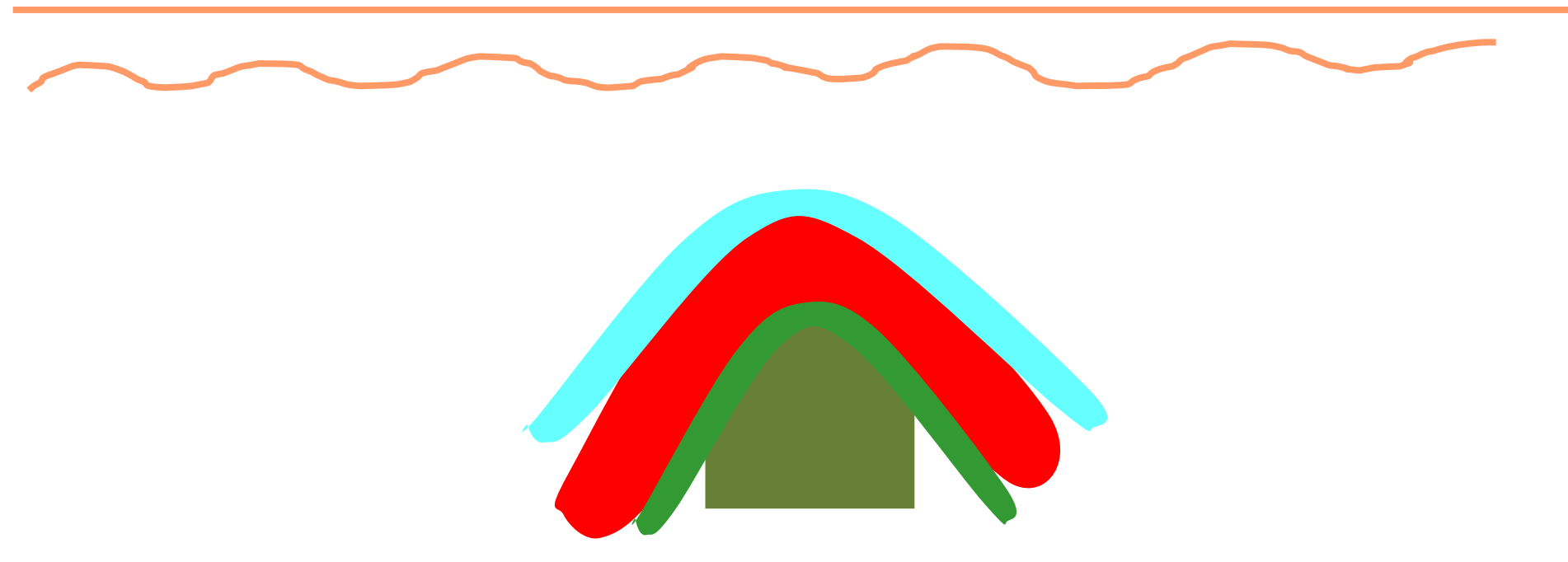


\section{Biological dose}
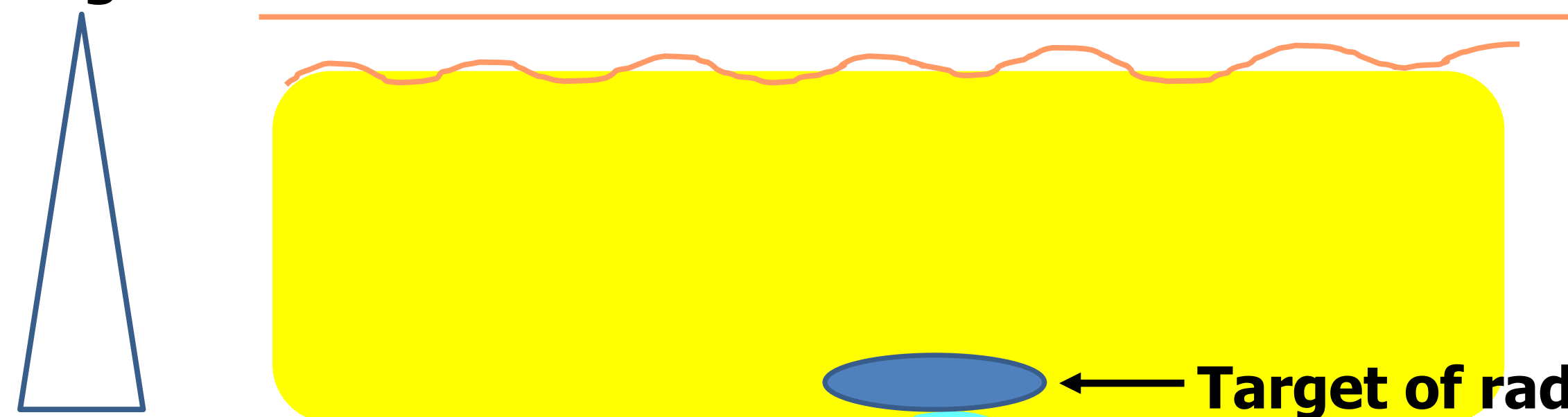

Target of radiation Tx.

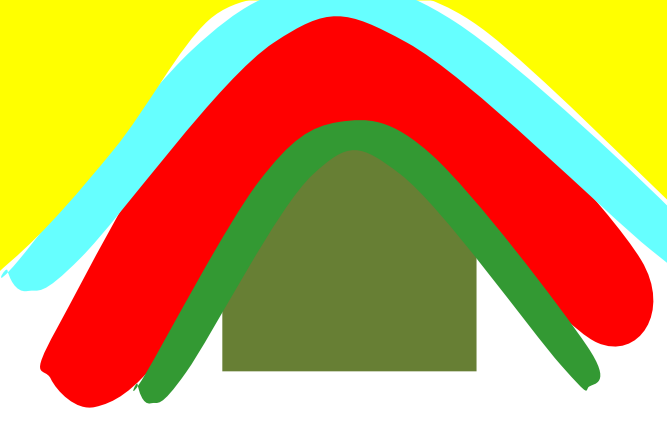


Figure $3 \mathrm{C}$

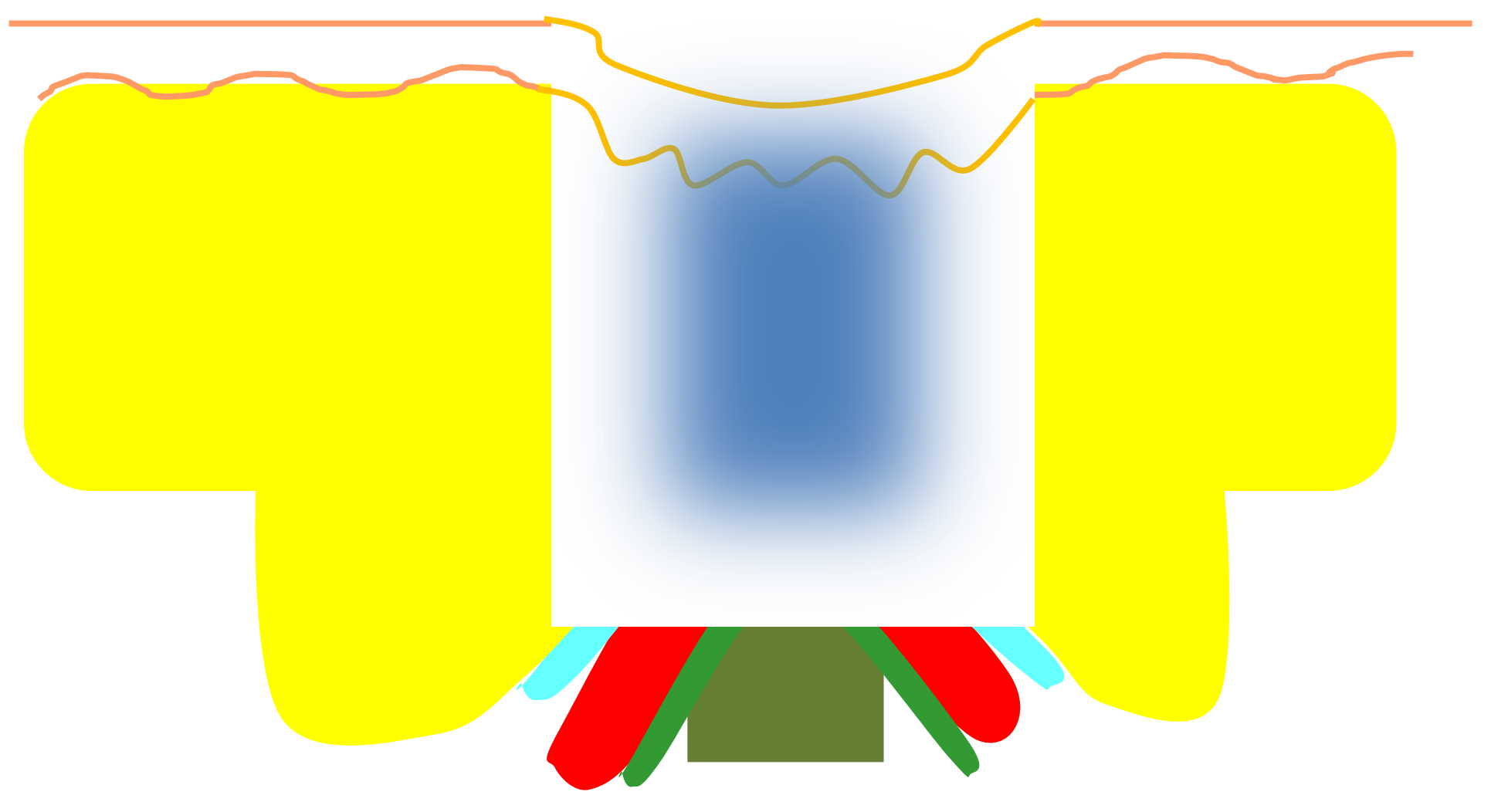


Figure 3D

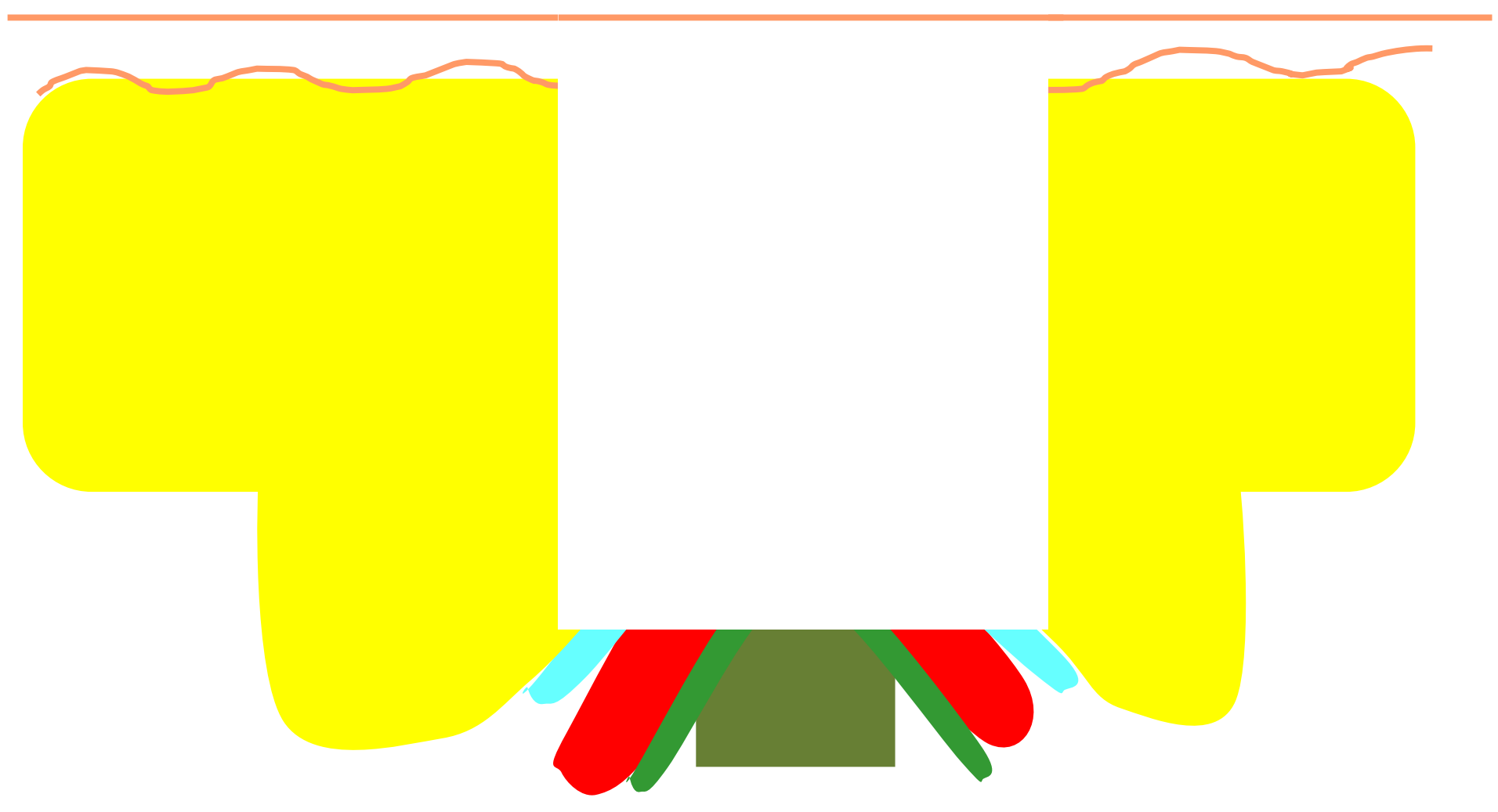


Figure 3E

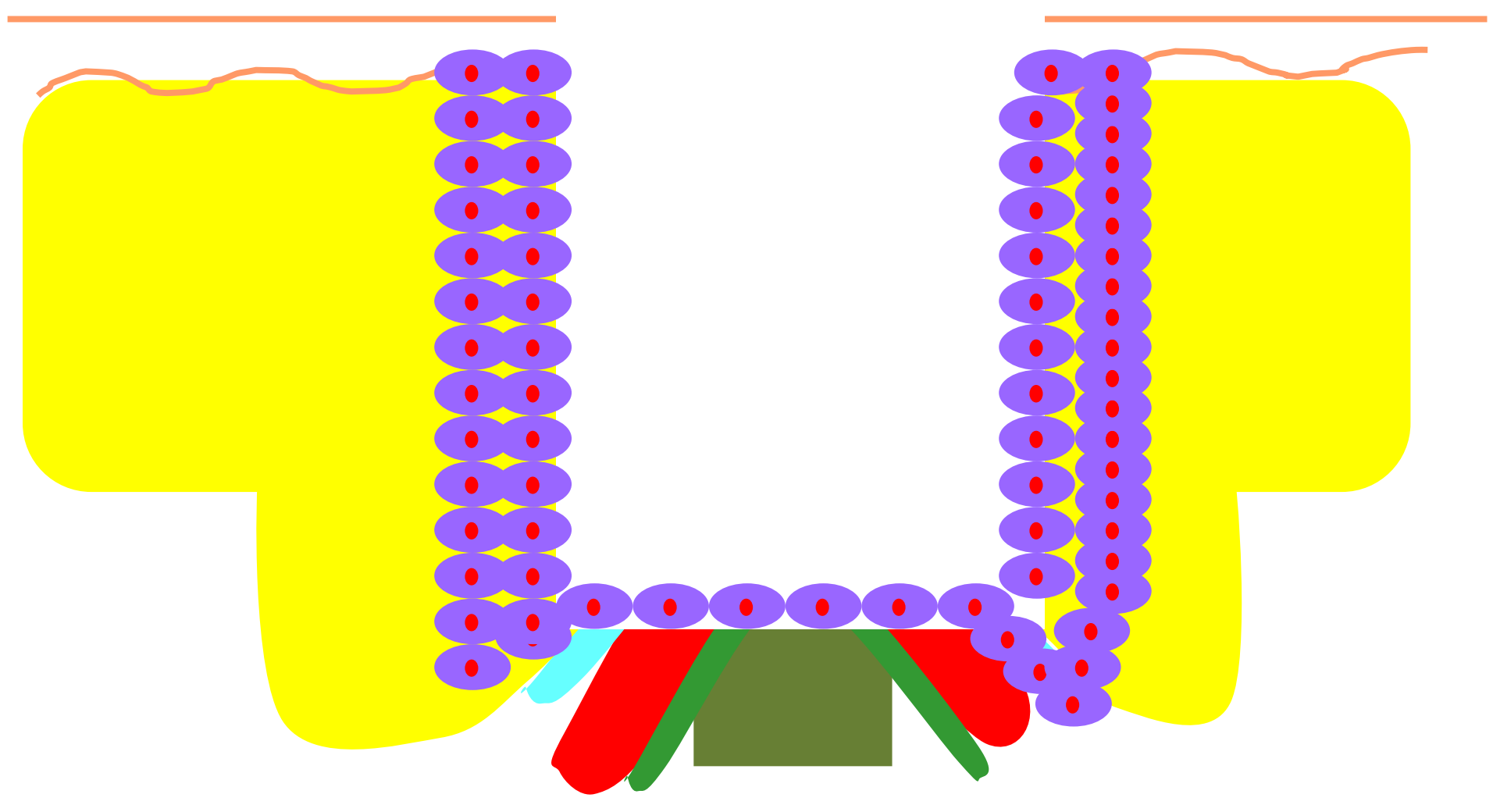


Figure 4

Pre-op

Intra-operative Intra-operative, Artificial dermis

\section{6 days}

72 days

\begin{tabular}{l|l|l}
1 & 2 & 3 \\
\hline 4 & 5 & 6
\end{tabular}


Figure 5

Day 2

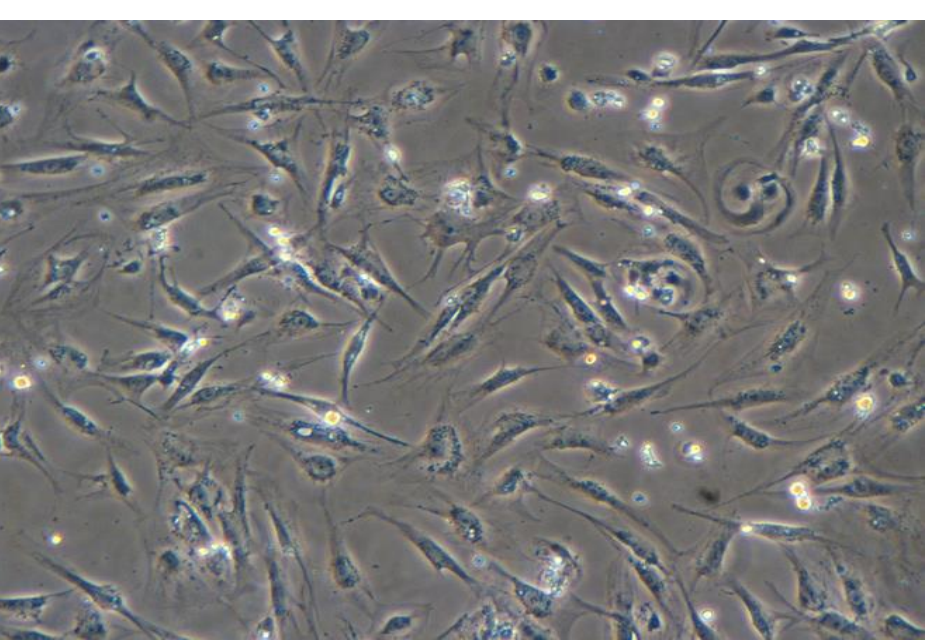

Day 16, induction Medium

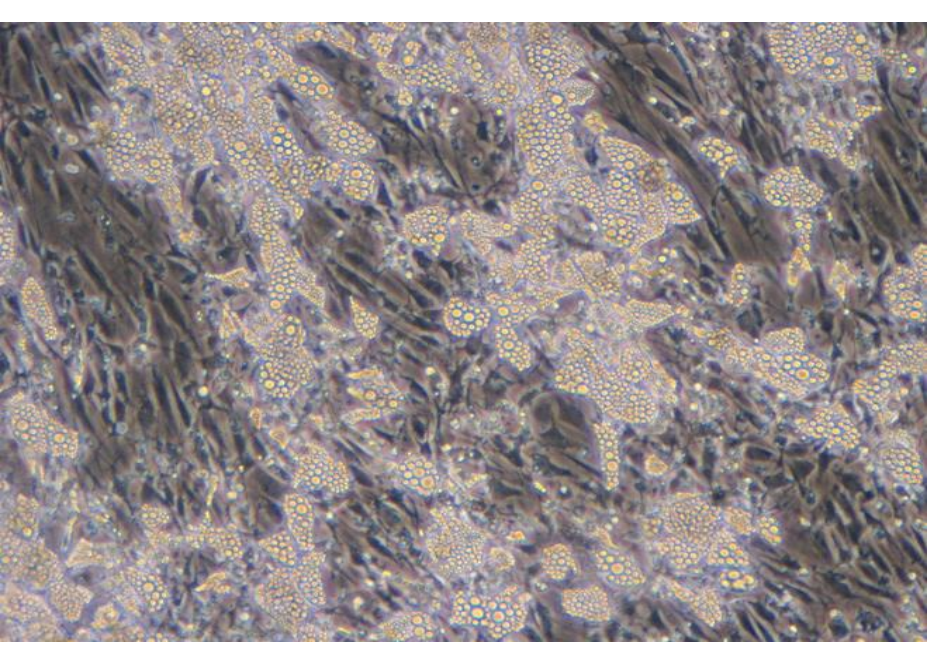

Day 9

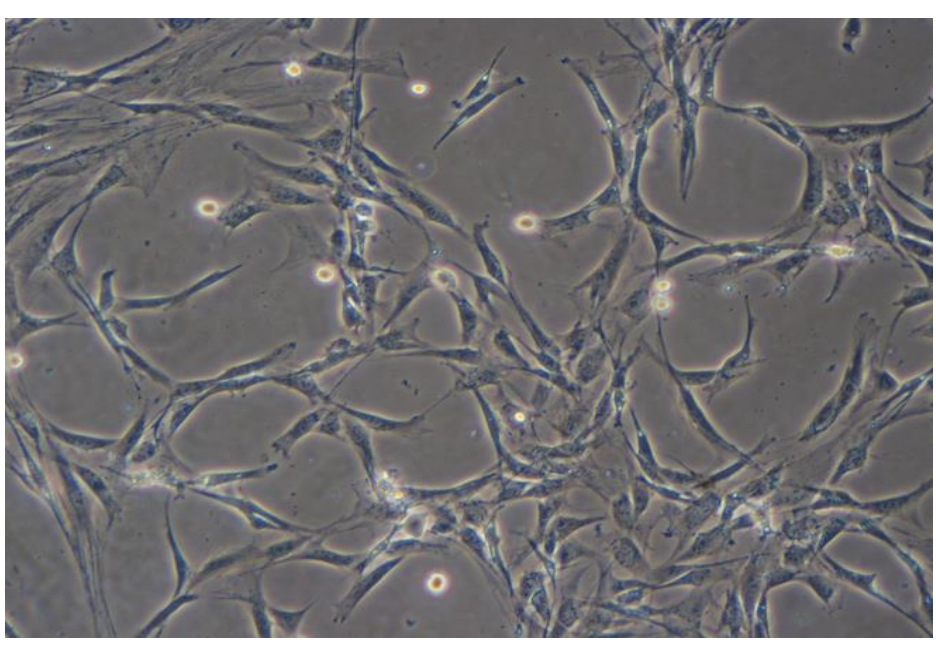

Day 16 , Oil Red-O

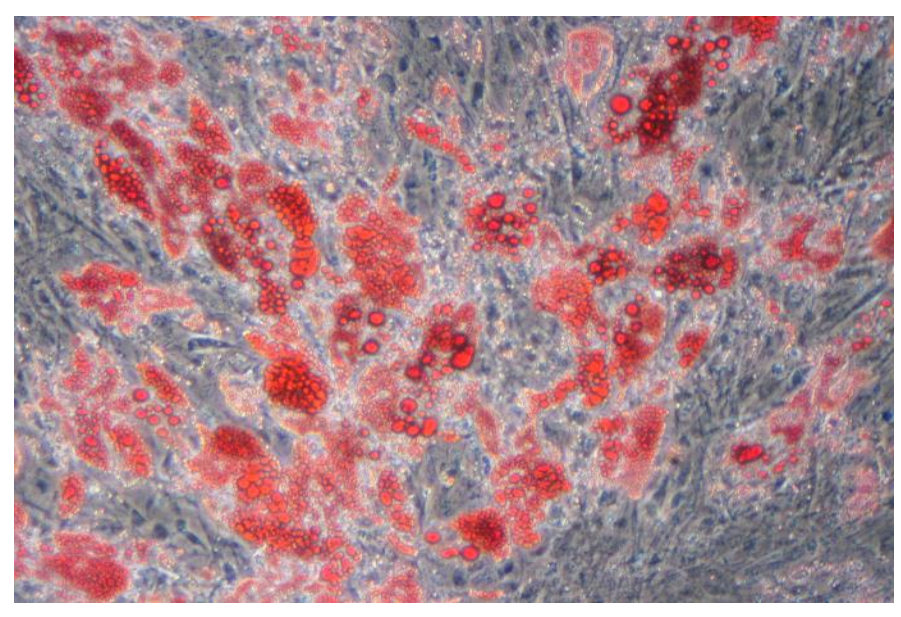

Day 16

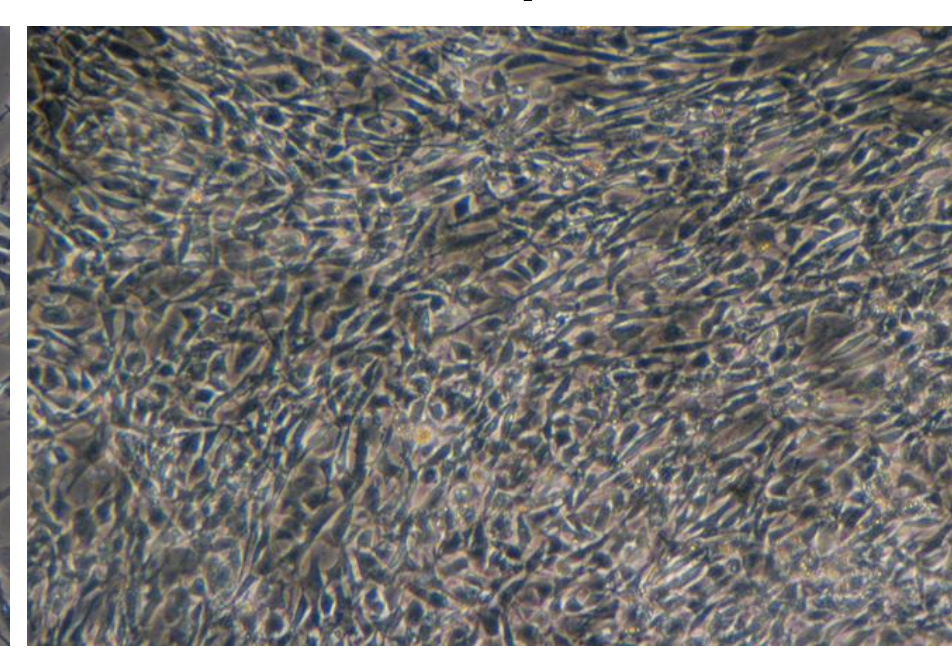

